\title{
ДОКУМЕНТОЗНАВСТВО, АРХІВОЗНАВСТВО
}

УДК 077:614(477)

\section{Цитування:}

Чередник Л. А. Використання електронних інформаційних ресурсів у сфері охорони здоров'я України. Бібліотекознавство. Документознавство. Інформологія. 2021. № 2. С. 57-62.

Cherednyk L. (2021). Use of electronic information resources in the field of healthcare of Ukraine. Library science. Record Studies. Informology. 2, 57-62 [in Ukrainian].

\section{ВИКОРИСТАННЯ ЕЛЕКТРОННИХ ІНФОРМАЦЙНИХ РЕСУРСІВ У СФЕРІ ОХОРОНИ ЗДОРОВ'Я УКРАЇНИ}

Мета роботи. У статті розглядаються актуальні питання впровадження електронних інформаційних ресурсів у сферу охорони здоров'я Украӥни. У науковій розвідці аналізуються найбільш поширені нині форми застосування е-документів у медичній сфері, а саме: укладання е-декларації із сімейним лікарем, онлайн-запис до лікаря, відеоконсультації з лікарем, е-реєстр інсулінозалежних пацієнтів, електронна медична карта, програма е-Малятко, е-лікарняний, створення профілю пацієнта, електронної карти вагітної жінки. Також авторка досліджує економічний ефект від впровадження різних видів електронних послуг, щзо набувають поширення у вітчизняній медицині. Методологія дослідження включає застосування описового методу, методу аналізу й синтезу для виявлення значущцості застосування електронних інформаційних ресурсів у медичній сфері. Наукова новизна роботи полягає у всебічній характеристиці найбільш типових форм застосування едокументів, щуо застосовуються у сучасній украйнській медичній галузі. Висновки. Детальний аналіз терміну "електронна охорона здоров'я» доводить, щзо він активно почав використовуватися у практичній діяльності з початку XXI століття. Значно раніше поняття «е-документ» увійшло в практику європейських та американських медиків, але впродовж останніх років у зв'язку з медичною реформою стає популярним і в Украйні. Розвиток інформаційних технологій суттєво змінює процес надання медичних послуг, переорієнтовуючи діяльність медичних установ на обслуговування, спрямоване на пацієнта. Використання електронних інформаційних ресурсів в системі охорони здоров'я має низку переваг, пов'язаних з економією часу, значним зростанням темпів надання послуг, включенням скорочення витрат тощуо. Крім того, завдяки можливості спілкування з пацієнтом за допомогою інформаційних засобів значно скорочується необхідність вимушених поӥздок, щзо надзвичайно важливо в умовах пандемії COVID-19. Уведення електронних документів унеможливлює їхню підробку та фальсифікацію. Електронний сервіс у медичній галузі Украӥни має широкі перспективи впровадження його нових форм.

Ключові слова: електронні інформаційні ресурси, медична сфера, е-медицина, е-документ, медична реформа. 
Cherednyk Lyudmila,

Ph.D., Associate Professor of Philology, Associate Professor of Ukrainian Studies, Culture and Documentation Department, National University «Poltava Yuri Kondratyuk Polytecnic»

\section{USE OF ELECTRONIC INFORMATION RESOURCES IN THE FIELD OF HEALTHCARE OF UKRAINE}

Purpose of the article. The article considers topical issues of the introduction of electronic information resources in the field of health care of Ukraine. Scientific research analyzes the most common forms of application of e-documents in the medical field, namely: concluding an e-declaration with a family doctor, online registration with a doctor, video consultations with a doctor, e-register of insulin-dependent patients, electronic medical card, e-medical program Baby, e-hospital, creating a patient profile, electronic card of a pregnant woman. The author also investigates the economic effect of the introduction of various types of electronic services that are becoming widespread in domestic medicine. The methodology includes the use of the descriptive method, method of analysis, and synthesis to identify the significance of the use of electronic information resources in the medical field. The scientific novelty lies in comprehensive characterization of most typical forms of e-documents used in the modern Ukrainian medical field. Conclusions. A detailed analysis of the term "e-health" proves that it has been actively used in practice since the beginning of the XXI century. Much earlier, the concept of "e-document" entered the practice of European and American physicians, but in recent years in connection with medical reform is becoming popular in Ukraine. The development of information technology significantly changes the process of providing medical services, reorienting the activities of medical institutions to patient-centered care. The use of electronic information resources in the health care system has a number of advantages associated with saving time, a significant increase in the pace of service delivery, the inclusion of cost reductions, and so on. In addition, the ability to communicate with the patient through the media significantly reduces the need for forced travel, which is extremely important in a COVID-19 pandemic. The introduction of electronic documents makes it impossible to forge and falsify them. Electronic service in the medical field of Ukraine has wide prospects for the introduction of its new forms. reform.

Key words: electronic information resources, medical sphere, e-medicine, e-document, medical

Актуальність теми дослідження. У сучасному світі інформаційні технології давно вже стали невід'ємною частиною усіх сфер людської діяльності. ІТ-технології досить успішно застосовуються і в медицині та передбачають як розробку нових підходів до аналізу процесів в системі охорони здоров'я, так і «чітке визначення вимог до структурованості інформації, що дозволить швидкий перегляд більшості первинних i облікових форм медичної документації, форм статистичної та іншої звітності» $[5,44]$. Крім того, впровадження інформаційної складової в медичну сферу внесло багато позитивних змін. Наприклад, вони допомагають лікареві проводити більш якісну i точну діагностику різних захворювань, «дозволяють накопичувати інформацію й ефективніше пі1 використовувати на всіх стадіях діагностики процесу лікування»[6, 6]. Тому вивчення особливостей застосування електронних інформаційних ресурсів в умовах переходу до е-медицини $\epsilon$ досить актуальним i перспективним.

Аналіз досліджень і публікацій. Дослідження проблем е-медицини останнім часом перебувають в центрі уваги багатьох як українських, так і зарубіжних науковців. Варто зазначити, що у процесі вивчення цього питання слід враховувати напрацювання в різних сферах охорони здоров'я, насамперед у галузі управління медичною системою, інформаційних технологій в медицині тощо. Серед наукових напрацювань необхідно виділити праці В. Авраменка, В. Качмаря, Р. Ахметшина, О. Баєва, Г. Зайця, Л. Дубчака, Р. Ларіна, А. Владзимирського, О. Балуєва та багатьох інших.

Метою роботи $€$ аналіз стану запровадження електронних інформаційних ресурсів у сучасну медичну галузь України та обгрунтування перспективи іiі розвитку й 
економічного ефекту.

Виклад основного матеріалу. Насамперед варто зазначити, що сам термін «електронна охорона здоров'я» виник давно (деякі вчені пов'язують його появу 3 дослідженнями академіків М. М. Амосова та В. М. Глушкова) [4], однак на практиці він став активно застосовуватися на початку нинішнього століття. Сьогодні відомо безліч визначень цього поняття, у яких акцент робиться на різні риси явища, що корелюються з терміном «е-медицина».

Головно, під терміном «електронна охорона здоров'я» (e-Health) слід розуміти не тільки «використання інформаційнокомунікаційних технологій для покращення рівня медицини, включаючи способи організації процесів в системі охорони здоров'я і суміжних сферах (науці, освіті, дослідницькій діяльності)», а й такі компоненти, як «органи управління, нормативно-правова база, стандарти i контроль відповідності, кадрові ресурси, інфраструктура, стратегія і модель залучення інвестицій» [7, 17]. Тобто електронна система охорони здоров'я $\epsilon$ інформаційним фундаментом i важливим інструментом реалізації медичної реформи, що проводиться в Україні.

В останні декілька років, щоправда, 3 великим запізненням у порівнянні із західними країнами, інформаційні технології обіймають важливе місце i в охороні здоров'я України.

Нині в Україні прийнято низку законодавчих актів у сфері медицини, адаптованих до вимог законодавства Європейського Союзу, що дозволяє впроваджувати в медичну галузь новітні технічні правила i стандарти, a саме: електронний пропис ліків (рецепт), електронну картку хворого, електронний запис тощо. Поєднання цих нововведень 3 безперервно зростаючим рівнем активності в галузі біомедичної та медичної інформатики виводять на принципово новий рівень значущості питання кодування, класифікації та стандартизації в медицині. Відомо, що системою кодування і класифікації в Україні традиційно є система МКБ. Однак, у 2017 році Міністерство охорони здоров'я України уклало угоду 3 WONCA (Всесвітньою організацією сімейних лікарів) про застосування на ліцензійних засадах системи кодування ICPC-2 [4].. Цю систему було розроблено WONCA для лікарів загальної практики і зараз однією з її офіційних мов $є$ й українська.

Ще одним 3 напрямків інтеграції до європейського співтовариства $є$ розробка i впровадження в повсякденну медичну практику клінічних настанов (рекомендацій), клінічних протоколів та стандартів медичної допомоги.

Зазначимо, що сьогодні в Україні вже працюють деякі електронні послуги. Зупинимося на них більш детально.

Так, через електронну систему охорони здоров'я громадяни України можуть укласти декларацію із сімейним лікарем.

В умовах пандемії COVID-19, коли скупчення людей $\epsilon$ небажаним, можна укласти декларацію онлайн. На сайті $\epsilon$ досить простий лайфхак, який демонструє схему цього процесу. Вона досить проста: у cервісі Helsi необхідно обрати медичний заклад поруч 3 місцем проживання. Також там можна знайти i лікаря (його краще шукати в системі за адресою, спеціальності або клініки). Потім зберегти його номер телефону і написати в одному з месенджерів запит щодо можливості укладання декларації [8, 119]. Однак варто додатково зателефонувати до лікарні і запитати, що потрібно для підписання декларації 3 лікарем. Можливо, що крім паспорта та ідентифікаційного коду знадобляться ще й інші документи. Після цього доведеться піти в лікарню і звернутися в реєстратуру, де уповноважена особа роздрукує декларацію (ii потрібно підписати), а потім співробітники лікарні разом 3 електронним підписом внесуть їі в систему. Після цього на номер прийде СМС 3 кодом, який потрібно сказати тому, хто вносив персональні дані в систему.

За даними Міністерства охорони здоров'я (2020р.), 30 мільйонів 600 тисяч українців вже уклали декларацію $з$ сімейним лікарем [7, 20].

Зручною формою $є$ й онлайн-запис до лікаря [4]. У більшості державних і приватних клінік уже функціонує система «Поліклініка без черг», яка уможливлює пацієнтам зробити запис на прийом i відвідати лікаря в зручний час. Слід 
підкреслити, що запис можна зробити як до свого дільничного чи сімейного лікаря, так $\mathrm{i}$ до будь-якого фахівця в медичній установі за потребою. Система досить проста, розрахована на середньостатистичного користувача інтернету i дає можливість зробити підтвердження входу за допомогою введення коду 3 SMS. Для додаткової зручності система «Поліклініка без черг» спрямовує створений талон з номером в SMS на телефон.

Електронний документообіг надає також можливість надання такої послуги, як створення профілю пацієнта. Для цього обов'язковим $є$ заповнення особистих даних (прізвище, ім'я, по батькові, дата народження та адресу місця проживання). Після цього кожен пацієнт повинен дати згоду на обробку даних для виконання Закону України «Про захист персональних даних» (необхідно натиснути кнопку «Добре») [8, 120]. До моменту підписання договору $з$ лікарем в полі «Сімейний лікар» відбивається лікар, який обслуговує ділянку за вказаною адресою місця проживання.

У зв'язку 3 поширенням пандемії COVID-19 особливої актуальності набуває послуга відеоконсультації лікарів, яка вже впроваджена в роботу деяких українських клінік. Наприклад, онлайн-консультацію можна пройти в усіх медичних центрах «ОН Клінік». Відеоконсультації лікаря проводяться в особистому кабінеті пацієнта - це спеціальний сервіс, який дозволяє зберігати медичні дані пацієнта, записуватися на прийом i відстежувати фінансову інформацію. Користуватися особистим кабінетом можна як з комп'ютера, так і з телефону. Для зручності можна встановити додаток ONline Clinic. Заявки на онлайн-консультації лікарів приймаються цілодобово.

Зазначимо, що онлайн-консультації мають багато переваг, оскільки допомагають уникнути зайвих соціальних контактів, які можуть привести до зараження коронавірусом, а також істотно економлять час пацієнта. Безумовно, дистанційне консультування пацієнтів підходить для тих випадків, коли не потрібне проведення очних діагностичних процедур (фізикального огляду, ЕКГ, УЗД тощо), а також для корекції та оцінки результату лікування, зокрема, при хронічних захворюваннях. За необхідності, лікар може направити пацієнта на проведення додаткових обстежень. Важливим $\epsilon$ i те, що під час онлайнконсультації пацієнт може обмінюватися 3 лікуючим лікарем файлами 3 результатами проведених обстежень. Після завершення дистанційної консультації лікар завантажує консультативний висновок в медичну карту в особистому кабінеті пацієнта.

31 квітня 2019 року Національна служба здоров'я України (НСЗУ) адмініструє програму реімбурсації лікарських засобів «Доступні ліки», впроваджену ще в 2017 році [4]. Метою програми є забезпечення кожного громадянина України доступними i життєво необхідними лікарськими засобами 3 доведеною ефективністю, які покращать якість їхнього життя і допоможуть запобігти виникненню ускладнень i передчасної смертності. Механізм реімбурсації поширюється на серцево-судинні захворювання, діабет II типу і бронхіальну астму. Пріоритетність надали лікуванню цих хвороб, оскільки саме вони найбільше впливають на показники смертності населення або істотно знижують якість життя пацієнта й ефективно лікуються на амбулаторному рівні.

У лютому 2021 року Міністерство охорони здоров'я України затвердило новий розширений перелік лікарських засобів (реєстр), які включено до програми «Доступні ліки». Так, було додано 3 нові міжнародні непатентовані назви (ацетилсаліцилова кислота, ніфедипін, варфарин). Ці препарати на українському ринку випускають під 24 торговими назвами. Їх виписують пацієнтам для профілактики інсульту та інфаркту, насамперед тим пацієнтам, які вже перенесли ці захворювання. Загалом, кількість лікарських засобів в новому реєстрі збільшилася на 33 позиції і тепер їх 297. 93 лікарські засоби пацієнти можуть отримати абсолютно безкоштовно. Інші ліки пацієнт отримує 3 невеликою доплатою. 31 квітня 2019 реалізацією цієї програми займається НСЗУ (Національна служба охорони здоров'я).

Важливо пам'ятати, що лікарські засоби, що підлягають реімбурсації, 31 квітня 2019 року виписують тільки через електронну систему охорони здоров'я в 
формі електронного рецепта. Як показала практика, електронний рецепт має низку переваг, а саме: мінімізація помилок при виписці; економія часу лікаря і пацієнта; можливість отримати ліки в будь-якій аптеці, яка має договір з НСЗУ на участь у програмі «Доступні ліки».

В Україні з 2016 року був введений в дію електронний реєстр пацієнтів, які потребують інсулінотерапії. У реєстрі зібрана інформація про всіх учасників та складові програми відшкодування вартості інсулінів: кожного лікаря, кожного пацієнта, кожну аптеку, кожен рецепт $[8,122]$. Це зроблено 3 метою визначити реальну кількість пацієнтів, яким потрібен інсулін, і правильно розрахувати потребу в ліках на рівні міста чи області. Завдяки впровадженню цього реєстру вдалося виявити низку порушень щодо фейкових інсулінозалежних пацієнтів.

Так, протягом першої половини 2021 року більшість областей України перейшли на користування єдиним реєстром i працюють за процедурою реімбурсації. На сьогодні, області, краще підготовлені до роботи через реєстр (Полтавська, Чернігівська, Вінницька), уже значно економлять на закупівлі препаратів інсуліну. Головно, введення реєстру дозволяє державі уникнути необгрунтованих закупівель на десятки мільйонів гривень. Відповідно, ця економія дозволить забезпечувати безперебійну поставку високоякісних препаратів інсуліну для кожного пацієнта.

Зручною новацією $є$ також електронна медична карта (ЕМК), в якій зберігається вся інформація про пацієнта: реєстраційні дані, результати медичних оглядів, антропометричні вимірювання, лабораторні обстеження та різноманітні графічні дані (УЗД, рентген і т. ін). Електронна медична карта значно економить час лікаря, оскільки при введенні даних не потрібно набирати текст за допомогою клавіатури. ЕМК пацієнта в тестовому режимі доступна сімейним лікарям, терапевтам і педіатрам медустанов, які підключені до електронної системи охорони здоров'я і мають контракт 3 НСЗУ. Згодом сімейний лікар буде вносити туди найважливішу медичну інформацію під час кожного візиту.

32020 року в Україні реалізується ще одна програма - «е-Малятко». Це комплексна система цифрових послуг, які входять в загальнодержавний онлайн-сервіс «Дія» та можуть бути отримані як через інтернет, так i офлайн. Ця програма передбачає поетапне спрощення надання державних послуг дітям у віці від 0 до 14 років. Сьогодні батьки можуть отримати повний перелік державних послуг для своїх дітей за допомогою надання тільки електронного заяви. За допомогою програми «е-Малятко» можна замовити 9 послуг, необхідних при народженні дитини. Дві 3 них $\epsilon$ базовими (державна реєстрація народження походження дитини (в свідоцтві про народження вказується інформація про матір та батька дитини)), а 7 надаються на вибір батьків (призначення допомоги при народженні, реєстрація місця проживання дитини тощо) [4].

Запровадження в Україні 31 травня 2021 року електронних лікарняних $\epsilon$ частиною загального переходу української медицини на електронний документообіг. Уряд затвердив новий порядок ведення електронного реєстру листків непрацездатності та надання інформації 3 нього. Така інформація замінить звичні паперові листки непрацездатності. Передбачається, що, завдяки реєстру, оформити лікарняний можна буде значно швидше, крім того - якнайшвидше отримати i нарахування грошей, які він передбачає. Тобто, уведення моделі електронного лікарняного полегшить роботу лікарів, зробить більш комфортним їхню взаємодія 3 пацієнтами, а останніх - 3 роботодавцями, зменшить паперове й бюрократичне навантаження i, нарешті, заощадить час i кошти всіх учасників процесу, а також знизить корупційні ризики (електронні лікарняні i рецепти не можна буде підробити).

Крім того, з 2021 року МОЗ України планує ввести ведення вагітності сімейними лікарями [4]. Йдеться про огляд у певних межах, який може проводити сімейний лікар. Вагітній жінці надається пакет безкоштовних послуг, а саме: збір аналізів; огляд; УЗД; кардіотокографія; лабораторна діагностика. Звичайно, передбачається й огляд акушерагінеколога.

Висновки. Розвиток інформаційних 
технологій суттєво змінює процес надання медичних послуг. Переорієнтація на обслуговування, спрямоване на пацієнта, створює сприятливі умови для ефективного медичного обслуговування.

Упровадження електронних процесів в систему охорони здоров'я сприяє ефективному застосуванню інформаційних ресурсів, а також уможливлює скорочення витрат, підвищення темпів надання послуг, економію часу, запобігання надмірного використання або небезпечну взаємодію лікарських препаратів, зменшення вимушених поїздок й усунення необхідності в наявності фізичної інфраструктури для лікування кожного пацієнта.

Необхідно також зазначити, що електронний сервіс в Україні невпинно зростає i має широкі перспективи впровадження його нових форм.

\section{Список використаних джерел}

1. Авраменко В. І., Качмар В. О. Формування основних напрямків розвитку інформаційних технологій в охороні здоров'я України на основі світових тенденції. Український журнал телемедицини та медичної телематики. 2011. Т. 9. № 2. C. 124-133. URL: http://nbuv.gov.ua/UJRN/Ujtm_2011_9_2_3 (дата звернення: 06.06.2021).

2. Ахметшин Р. Л. Можливі соціально-правові проблеми розвитку i розповсюдження телемедицини в Україні. Буковинський медичний вісник. 2013. Т. 17. № 4. C. 219-223. URL: http://nbuv.gov.ua/UJRN/bumv_2013_17_4_57 (дата звернення: 03.06.2021).

3. Баєва О. В. Основи менеджменту охорони здоров'я. Київ : МАУП, 2007. 328 с.

4. Глобальні прогнози та тенденції у сфері IT-медицини. URL: https://evergreens.com.ua/ua/articles/telemedicine-vs-telehealth.html (дата звернення: 28.04.2020).

5. Державна політика у сфері охорони здоров'я : кол. моногр. : у 2 ч. / кол. авт. ; упоряд. проф. Я.Ф. Радиш; передм. та заг. ред. проф. М.М. Білинської, проф. Я.Ф. Радиша. Київ : НАДУ, 2013. Ч. 1. $396 \mathrm{c}$.

6. Мінцер О.П. Концепція інформатизації охорони здоров’я в Україні. Медична інформатика та інженерія, № 3, 2012. С.5-29.

7. Радзішевська Є. Б., Висоцька В.О. Інформаційні технології в медицині. E-health / за ред. В. Г. Кнігавка; Харківський національний медичний університет. Харків : ХНМУ, 2019. 72 с.

8. Шушпанов Д.Г. Доступність та якість медичних товарів та послуг в Україні: соціальноекономічний аспект. Регіональні аспекти розвитку і розміщення продуктивних сил України. 2018. № 23. С. $118-124$.

\section{References}

1. Avramenko, V. I., Kachmar, V. O. (2011). Formation of the main directions of development of information technologies in health care of Ukraine on the basis of world tendencies. Ukrayinskyj zhurnal telemedycyny ta medychnoyi telematyky, T. 9, 2, 124-133 [in Ukrainian].

2. Axmetshyn, R. L. (2013). Possible socio-legal problems of development and dissemination of telemedicine in Ukraine. Bukovynskyj medychnyj visnyk, T. 17, 4, 219-223 [in Ukrainian].

3. Bayeva, O. V. (2007). Basics of health management. Kyiv : MAUP [in Ukrainian].

4. Global forecasts and trends in the field of IT medicine. URL: https://evergreens.com.ua/ua/articles/telemedicine-vs-telehealth.html [in Ukrainian].

5. Public health policy: kol. Monogr (2013). Kyyiv : NADU, Ch. 1[in Ukrainian].

6. Mincer, O. P. (2012). The concept of health care informatization in Ukraine. Medychna informatyka ta inzheneriya, 3, 5-29 [in Ukrainian].

7. Radzishevska, Ye. B., Vysoczka, V. O. (2019). Information technology in medicine. E-health. Kharkiv : XNMU [in Ukrainian].

8. Shushpanov, D. G. (2018). Availability and quality of medical goods and services in Ukraine: socio-economic aspect. Regionalni aspekty rozvytku i rozmishhennya produktyvnyx sy 1 Ukrayiny, 23, 118124 [in Ukrainian]. 